Supporting Information for

\title{
China's Ban on Phenylarsonic Feed Additives, A Major Step towards Reducing the Human and Ecosystem Health Risk from Arsenic
}

\author{
Yuanan Hü ${ }^{1}$,Hefa Cheng ${ }^{2 *}$, Shu Tao ${ }^{2}$, Jerald L. Schnoor ${ }^{3}$
}

1 MOE Laboratory of Groundwater Circulation and Evolution

School of Water Resources and Environment

China University of Geosciences (Beijing)

Beijing 100083, China

2 MOE Key Laboratory for Earth Surface Processes

College of Urban and Environmental Sciences

Peking University

Beijing 100871, China

3 Department of Civil and Environmental Engineering

University of Iowa

Iowa City, Iowa 52242, USA

Submitted to: Environmental Science \& Technology

Date: Oct. 7, 2019

Number of Pages: 19

Number of Tables: 5

Number of Figures: 3 


\section{Assessment of public health risk from $i$-As exposure through chicken consumption in}

\section{China before and after enforcement of the phenylarsonic feed additive ban}

In the study, only the carcinogenic risk of $i$-As exposure from consumption of chicken meat was estimated due to the lack of data for $i$-As levels in pork, although phenylarsonic feed additives were also commonly used in swine production. In health risk assessment, CSF is established based on the relationship between dose and response, and is used to quantify the carcinogen toxicity of the substance of interest. Currently, the only CSF for $i$-As listed in the Integrated Risk Information System (IRIS) is $1.5(\mathrm{mg} / \mathrm{kg} / \mathrm{day})^{-1}$, which is derived from the research on skin cancer from $i$-As exposure. ${ }^{1}$ In 2010, the U.S. Environmental Protection Agency (USEPA) proposed a new CSF of 25.7 (mg/kg /day) ${ }^{-1}$, which corresponds to combined lung and bladder cancer from $i$ As exposure. ${ }^{2}$ Although it is still under external review and has not been finalized in the IRIS, the new CSF value has been adopted by researchers in assessing the public health risk of $i$-As exposure. ${ }^{3-7}$

The daily intake rates of chicken meat for urban and rural residents in China were estimated using the reported annual poultry consumption rates for 31 provinces and municipalities in the Statistical Yearbook of China. ${ }^{8}$ Table S5 summarizes the detailed intake rates and population sizes in all provinces and municipalities. The urban residents in China had slightly higher intake rates than rural residents in most provinces, which resulted from the obvious income inequality between the urban and rural households. Significant uneven geographical distribution of the chicken consumption rate was observed, with people in southern and eastern China having higher chicken meat consumption rates than those in the north and west. The consumption rates of chicken meat in Hainan, Guangdong, and Guangxi were approximately 2 times of the national average, and 
approximately 4 times of the average for northern China. It should be noted that the 11 provinces with the highest consumption rates of chicken meat (namely, Guangdong, Hainan, Guangxi, Shanghai, Fujian, Chongqing, Sichuan, Hunan, Zhejiang, Jiangsu, and Anhui) hosted approximately $45 \%$ of the country's total population in 2017.

\section{Impact of phenylarsonic feed additive phase-out on market prices of chickens}

Figure S2a shows the monthly wholesale and retail prices of broiler composite in the U.S. between 2007 and 2018. A generally increasing trend was observed for both the wholesale and retail prices in the period before FDA's withdrawal of the approval for ROX (January 2007 - December 2012), while both of them decreased slightly after January 2013. These results suggest that complete removal of phenylarsonic feed additives in animal farming did not significantly impact the prices of chickens on the markets and thus the production costs in the U.S. It might be too early to assess the economic cost of the phenylarsonic feed additive ban on poultry and swine production in China as it only became effective nationwide on May 1, 2019. Nonetheless, the use of $p$-ASA and ROX on chickens had been banned in Fujian province since 2008. Fujian is a major livestock and poultry production base in southern China. Figure S2b shows that farm-gate prices of fast- and medium-growing chickens in Fujian were not significantly different from those of national averages between June 2018 and July 2019. It should be noted that the farm-gate prices of chickens had significant seasonal fluctuations due to the dynamic changes in the supply, costs of feeds, as well as the price variations of pork. Overall, the prohibition of phenylarsonic feed additive use in Fujian province did not result in chickens with higher farm-gate prices, which demonstrates that the costs of chicken production in the province were not significantly different from those in the other production bases in China. Together, both the historical price data in the 
U.S. and the farm-gate price data in the province prohibiting phenylarsonic feed additive use compared to the rest of China consistently show that phasing out their use had little extra economic cost to the producers. 


\section{Tables}

Table S1. Summary of the chemical structures of phenylarsonic feed additives and their use in food animal production.

$\begin{aligned} & \text { Phenylarsonic } \\ & \text { feed additive }\end{aligned}$
Roxarsone

\section{Approved}

animal use

$$
\text { Chickens, turkeys, and pigs } \quad \text { Chickens, turkeys, and pigs }
$$

Chickens and turkeys

Chickens and turkeys

\begin{tabular}{|c|c|c|c|c|}
\hline Approval time & $\begin{array}{c}1944 \text { in U.S.; } \\
1996 \text { in China; } \\
\text { No approval received in Europe. }\end{array}$ & $\begin{array}{l}1964 \text { in U.S.; } \\
1993 \text { in China; } \\
\text { No approval received in } \\
\text { Europe. }\end{array}$ & $\begin{array}{l}1964 \text { in U.S.; } \\
\text { Not used in China and } \\
\text { Europe. }\end{array}$ & $\begin{array}{l}1964 \text { in U.S.; } \\
\text { Not used in China and Europe. }\end{array}$ \\
\hline $\begin{array}{l}\text { Typical dose in } \\
\text { animal feed }\end{array}$ & $25-50 \mathrm{mg} / \mathrm{kg}$ & $50-100 \mathrm{mg} / \mathrm{kg}$ & $190 \mathrm{mg} / \mathrm{kg}$ & $375 \mathrm{mg} / \mathrm{kg}$ \\
\hline Purpose & $\begin{array}{l}\text { To prevent coccidiosis and } \\
\text { increase weight gain in chickens }\end{array}$ & $\begin{array}{l}\text { To prevent coccidiosis and } \\
\text { increase weight gain in } \\
\text { chickens and pigs, and to }\end{array}$ & $\begin{array}{l}\text { To prevent } \\
\text { histomoniasis }\end{array}$ & $\begin{array}{l}\text { To treat amebiasis as an antiprotozoal } \\
\text { drug, and to increase weight gain and } \\
\text { control histomoniasis in turkeys }\end{array}$ \\
\hline
\end{tabular}


and pigs, and to create a

"healthy color" in poultry meat

create a "healthy color" in

poultry meat

(blackhead disease) in

turkeys and chickens
1998 in Europe;

Phase-out time 2013 in U.S.;

2019 in China.

\section{8 in Europe;}

2013 in U.S.;

2015 in U.S.

2013 in U.S.

2019 in China. 
Table S2. Makeup of the chicken market in China between 2006 and 2016.

\begin{tabular}{lcccccc}
\hline Year & $\begin{array}{c}\text { Production }^{\mathrm{a}} \\
\text { (million } \\
\text { tonnes) }\end{array}$ & $\begin{array}{c}\text { Consumption } \\
\text { (million } \\
\text { tonnes) }\end{array}$ & $\begin{array}{c}\text { Export }^{\mathrm{a}} \\
\text { thousand }_{\text {tonnes }}\end{array}$ & $\begin{array}{c}\text { Import }^{\mathrm{a}} \\
\text { (thousand } \\
\text { tonnes) }\end{array}$ & $\begin{array}{c}\text { Share of export } \\
\text { in total } \\
\text { production (\%) }\end{array}$ & $\begin{array}{c}\text { Share of import in } \\
\text { total consumption } \\
(\%)\end{array}$ \\
\hline 2006 & 10.4 & 10.7 & 96.9 & 573.6 & 0.94 & 5.37 \\
\hline 2007 & 11.3 & 11.8 & 125.9 & 775.8 & 1.11 & 6.58 \\
\hline 2008 & 11.8 & 12.3 & 128.2 & 790.6 & 1.08 & 6.45 \\
\hline 2009 & 12.1 & 12.5 & 131.6 & 724.6 & 1.09 & 5.78 \\
\hline 2010 & 12.6 & 12.9 & 165.2 & 518.9 & 1.32 & 4.03 \\
\hline 2011 & 13.2 & 13.5 & 168.6 & 386.2 & 1.28 & 2.87 \\
\hline 2012 & 13.7 & 14.0 & 147.6 & 474.5 & 1.08 & 3.39 \\
\hline 2013 & 13.3 & 13.6 & 153.3 & 541.2 & 1.15 & 3.98 \\
\hline 2014 & 13.0 & 13.3 & 172.1 & 441.5 & 1.32 & 3.32 \\
\hline 2015 & 13.4 & 13.7 & 189.1 & 397.0 & 1.41 & 2.89 \\
\hline 2016 & 12.3 & 12.8 & 177.8 & 571.3 & 1.44 & 4.46 \\
\hline
\end{tabular}

Note:

a - Data from Market Assessment and Investment Prospect Forecasting Report on Pig Slaughtering Industry in China between 2018 and 2024 published by Intelligence Research Group (Beijing, China), which were compiled from data in 2018 China Statistical Yearbook and data released by the General Administration of Customs of the People's Republic of China. 
Table S3. Makeup of the pork market in China between 2011 and 2017.

\begin{tabular}{lcccccc}
\hline Year & $\begin{array}{c}\text { Production }^{\mathrm{a}} \\
\text { (million } \\
\text { tonnes) }\end{array}$ & $\begin{array}{c}\text { Consumption } \\
\text { (million } \\
\text { tonnes) }\end{array}$ & $\begin{array}{c}\text { Export }^{\mathrm{b}} \\
\text { thousand }_{\text {tonnes }}\end{array}$ & $\begin{array}{c}\text { Import }^{\mathrm{b}} \\
\text { (thousand } \\
\text { tonnes) }\end{array}$ & $\begin{array}{c}\text { Share of export } \\
\text { in total } \\
\text { production (\%) }\end{array}$ & $\begin{array}{c}\text { Share of import in } \\
\text { total consumption } \\
(\%)\end{array}$ \\
\hline 2011 & 51.32 & 51.70 & 79.5 & 467.7 & 0.15 & 0.90 \\
\hline 2012 & 54.44 & 54.89 & 66.2 & 522.2 & 0.12 & 0.95 \\
\hline 2013 & 56.19 & 56.70 & 73.4 & 583.5 & 0.13 & 1.03 \\
\hline 2014 & 58.21 & 58.68 & 91.5 & 564.3 & 0.16 & 0.96 \\
\hline 2015 & 56.45 & 57.16 & 71.5 & 777.5 & 0.13 & 1.36 \\
\hline 2016 & 54.25 & 55.83 & 48.5 & 1620.3 & 0.09 & 2.90 \\
\hline 2017 & 54.52 & 55.68 & 51.3 & 1216.8 & 0.09 & 2.19 \\
\hline
\end{tabular}

Notes:

a - Data from Market Survey and Investment Prospect Forecasting Report on Chicken Industry in China between 2019 and 2025 published by Huaon Industry Research Institute (Beijing, China), which were compiled from public data;

b - Data from Footprint of China's Broiler Chicken Industry of the Past 40 Years Since the Opening Up published by Shanghai Lyja Cultural Media Co (Shanghai, China), which were compiled from public data. 
Table S4. Summary of the major regulatory rules on the production and use of phenylarsonic feed additives in China.

\begin{tabular}{llll}
\hline Regulatory rule & Effective date & Purpose & Specific requirements \\
\hline $\begin{array}{l}\text { The Maximum Residue Limits } \\
\text { of Veterinary Drugs in Animal }\end{array}$ & Feb. 4, 1994 & $\begin{array}{l}\text { To promote safe } \\
\text { use of veterinary } \\
\text { drugs, and protect } \\
\text { public health }\end{array}$ & $\begin{array}{l}\text { The following maximum residue limits for total As are set (due to } \\
\text {-ASA use): }\end{array}$ \\
$\begin{array}{l}\text { Standards (Ministry of } \\
\text { Agriculture Document No. } 5\end{array}$ & $\begin{array}{l}\text { Pig liver and kidney }-2 \mathrm{mg} / \mathrm{kg} ; \\
\text { (1994) on Animal Farming) }\end{array}$ & $\begin{array}{l}\text { Pig muscle and meat byproduct }-0.5 \mathrm{mg} / \mathrm{kg} ; \\
\text { Chicken muscle and egg }-0.5 \mathrm{mg} / \mathrm{kg} ;\end{array}$ \\
& Chicken meat byproduct $-2 \mathrm{mg} / \mathrm{kg}$.
\end{tabular}

The Maximum Residue Limits of Veterinary Drugs in Animal Food Products (Ministry of Agriculture Document No. 7 (1997) on Animal Farming)

Sept. 1, 1997

To promote safe use of veterinary drugs, and protect public health

The following maximum residue limits for total As are set (due to $p$-ASA use):

Pig liver and kidney - $2 \mathrm{mg} / \mathrm{kg}$;

Pig muscle and meat byproduct $-0.5 \mathrm{mg} / \mathrm{kg}$;

Chicken muscle and egg - $0.5 \mathrm{mg} / \mathrm{kg}$;

Chicken meat byproduct - $2 \mathrm{mg} / \mathrm{kg}$.

The Maximum Residue Limits of Veterinary Drugs in Animal Food Products (Ministry of Agriculture Document No. 17 (1999) on Animal Farming)

Safe Use Specifications of Feed Drug Additives
Sept. 13, 1999 To strengthen the management of veterinary drug residues and protect the safety of animal food products

Jul. 3, 2001
To strengthen the management of
The following maximum residue limits for total As are set (due to $p$-ASA use):

Pig liver and kidney - $2 \mathrm{mg} / \mathrm{kg}$;

Pig muscle and meat byproduct $-0.5 \mathrm{mg} / \mathrm{kg}$;

Chicken muscle, meat byproduct, and egg $-0.5 \mathrm{mg} / \mathrm{kg}$.

The following requirements are set for the use of $p$-ASA and ROX 
(Ministry of Agriculture

Announcement No. 168) veterinary drugs,

further standardize

and guide the

rational use of feed

additives, and

prevent abuse of

feed additives in chicken and swine production:

p-ASA dosage in feed - $100 \mathrm{mg} / \mathrm{kg}$;

ROX dosage in feed - 25 or $50 \mathrm{mg} / \mathrm{kg}$;

Withdrawal period - 5 days;

Use on egg-producing chickens is prohibited.
The Maximum Residue Limits of Veterinary Drugs in Animal

Food Products (Ministry of Agriculture Announcement No. 235)
Dec. 24, 2002 To strengthen the management of veterinary drugs and protect the safety of animal food products
The following maximum residue limits for total As are set (due to p-ASA and ROX use):

Pig liver and kidney - $2 \mathrm{mg} / \mathrm{kg}$;

Pig muscle and meat byproduct $-0.5 \mathrm{mg} / \mathrm{kg}$;

Chicken muscle, meat byproduct, and egg $-0.5 \mathrm{mg} / \mathrm{kg}$.

$p$-ASA and ROX should only be produced by the qualified manufacturers approved by the Ministry of Agriculture;

ROX and its pre-mix, and $p$-ASA and its premix that were approved by local government agencies should no longer be produced, marketed, or used;

safeguard the safety, effectiveness, and quality of veterinary drugs, and protect the safety of animal food products
Local veterinary drug administrative agencies should abolish the approval document numbers of the products approved by them by the end of the year.
Notification on Review of the Approval Document Numbers of Organoarsenic Compounds (Ministry of Agriculture

\section{1}

To control the approval of organoarsenic compounds, which
Manufacturers approved for the production of organoarsenic drugs can still apply for permit of producing pre-mix of the same types, while new application from other manufacturers will not be accepted; 
Document No. 421 (2011) on

Veterinary Drugs) have been included

in the programme

for re-evaluation of

approved

veterinary drugs.
New document numbers will be issued to the manufacturers, who received approval document numbers of organoarsenic compounds after 2005, and applied for their renewal 6 months before expiration, while delayed applications will no longer be accepted.
Ban on the Use of Three

Veterinary Drugs,

Olaquindox, $p$-Arsanilic Acid, and Roxarsone, on Foodproducing Animals (Ministry of Agriculture Announcement No. 2638)
Jan. 11, 2018

To protect the safety of animal food products and public health, and safeguard the safety of ecosystem.
New approval document numbers will no longer be issued for olaquindox, $p$-ASA, ROX, and veterinary drugs based on them;

The production of olaquindox, $p$-ASA, ROX, and veterinary drugs based on them will be banned after May 1, 2018, while the products produced before Apr. 30, 2018 can still be distributed and used within a year;

The distribution and use of olaquindox, $p$-ASA, ROX, and veterinary drugs based on them will be banned after May 1, 2019. 
Table S5. Population and per capita daily intake rate of chicken meat for all provinces and municipalities in China (data from National Bureau of Statistics ${ }^{9}$ ).

\begin{tabular}{|c|c|c|c|c|}
\hline \multirow{2}{*}{ Province/municipality } & \multicolumn{2}{|c|}{ Population (million) } & \multicolumn{2}{|c|}{ Daily intake rate per capita (g/day) } \\
\hline & Urban & Rural & Urban residents & Rural residents \\
\hline Beijing & 18.78 & 2.93 & 11.0 & 7.67 \\
\hline Tianjin & 12.91 & 2.66 & 11.4 & 7.81 \\
\hline Hebei & 41.36 & 33.83 & 9.83 & 6.17 \\
\hline Shanxi & 21.23 & 15.79 & 5.50 & 3.31 \\
\hline Inner Mongolia & 15.68 & 9.61 & 11.2 & 8.46 \\
\hline Liaoning & 29.49 & 14.20 & 11.7 & 6.44 \\
\hline Jilin & 15.39 & 11.78 & 9.60 & 9.59 \\
\hline Heilongjiang & 22.50 & 15.38 & 10.8 & 11.2 \\
\hline Shanghai & 21.21 & 2.97 & 24.4 & 25.6 \\
\hline Jiangsu & 55.21 & 25.08 & 21.7 & 16.2 \\
\hline Zhejiang & 38.47 & 18.10 & 22.0 & 17.3 \\
\hline Anhui & 33.46 & 29.09 & 19.7 & 19.3 \\
\hline Fujian & 25.34 & 13.77 & 20.5 & 26.1 \\
\hline Jiangxi & 25.24 & 20.98 & 19.6 & 12.8 \\
\hline Shandong & 60.62 & 39.44 & 12.4 & 9.84 \\
\hline Henan & 47.95 & 47.64 & 12.5 & 8.13 \\
\hline Hubei & 35.00 & 24.02 & 12.5 & 7.67 \\
\hline Hunan & 37.47 & 31.13 & 20.2 & 20.9 \\
\hline Guangdong & 78.02 & 33.67 & 37.0 & 45.1 \\
\hline Guangxi & 24.04 & 24.81 & 38.5 & 36.8 \\
\hline
\end{tabular}




\begin{tabular}{lcccc} 
Hainan & 5.37 & 3.89 & 43.9 & 33.6 \\
Chongqing & 19.71 & 11.05 & 27.1 & 15.2 \\
Sichuan & 42.17 & 40.85 & 22.9 & 19.4 \\
Guizhou & 16.48 & 19.32 & 14.3 & 6.60 \\
Yunnan & 22.41 & 25.59 & 15.6 & 13.8 \\
Tibet & 1.04 & 2.33 & 9.78 & 0.18 \\
\hline Shaanxi & 21.78 & 16.57 & 7.29 & 3.17 \\
\hline Gansu & 12.18 & 14.08 & 10.0 & 7.38 \\
\hline Qinghai & 3.17 & 2.81 & 8.09 & 5.28 \\
\hline Ningxia & 3.95 & 2.87 & 11.7 & 11.3 \\
\hline Xinjiang & 12.07 & 12.38 & 14.8 & 8.67 \\
\hline
\end{tabular}




\section{Figures}
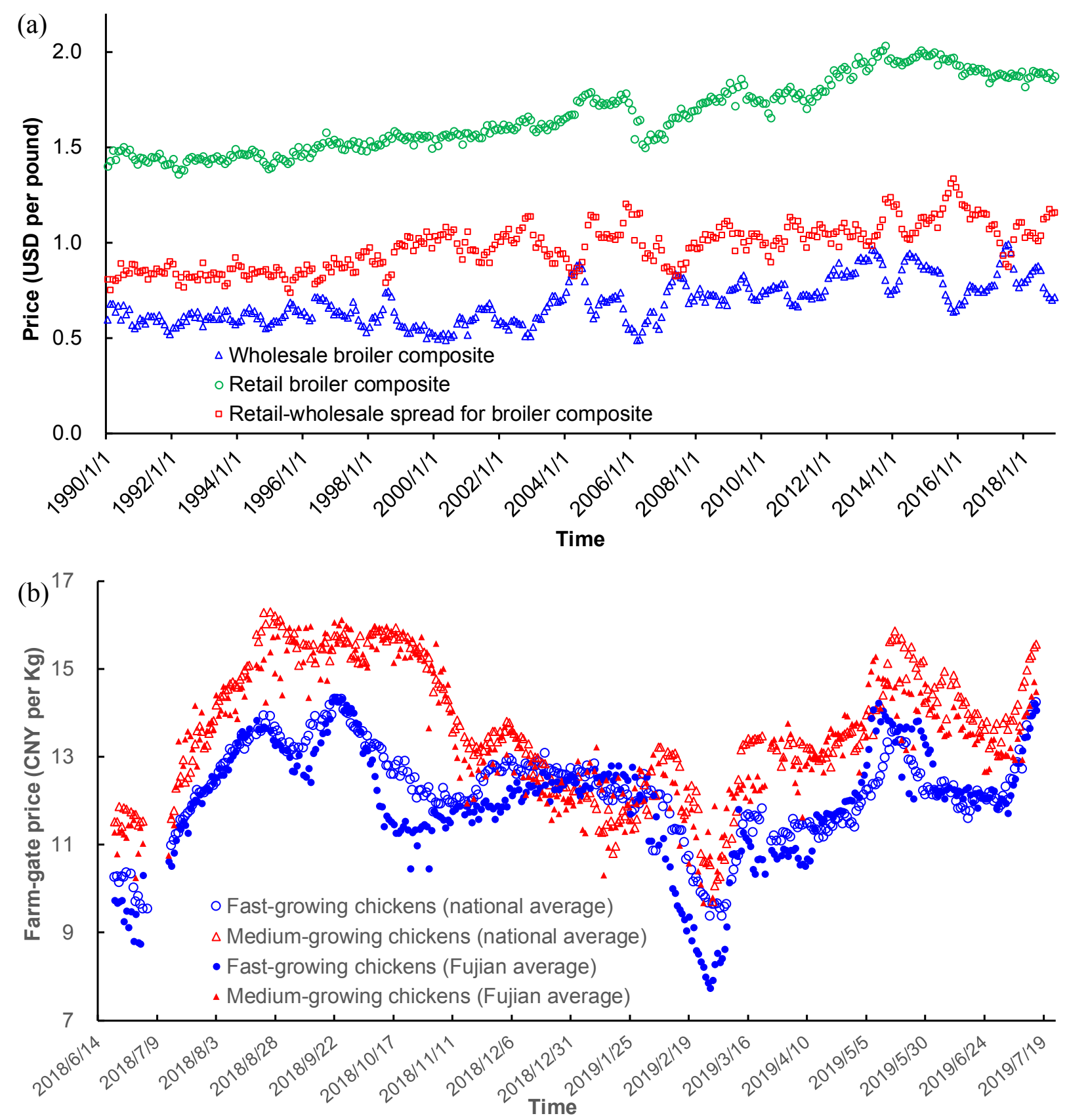

Figure S1. Prices of chickens with and without enforcement of the ban on phenylarsonic feed additive use in poultry production: (a) Monthly wholesale and retail prices of broiler composite in the U.S. from 2007 to 2018 (use of phenylarsonic feed additives on broiler production was 
banned in 2013); and (b) Daily farm-gate prices of fast- and medium-growing chickens in China, along with those in Fujian province, where the use of phenylarsonic feed additives on chickens was banned back in 2008, between June 2018 and July 2019. The U.S. data were from the Price Spreads from Farm to Consumer dataset of the U.S. Department of Agriculture (https://www.ers.usda.gov/data-products/meat-price-spreads/), while the Chinese data were from the chicken price index of Xinmu Net (http://www.xinm123.com/), a major information platform for livestock and poultry products in China. 
(a)

South China

TDI $(i-A s)=52.5 \mu \mathrm{g} /$ person $/ \mathrm{d}$

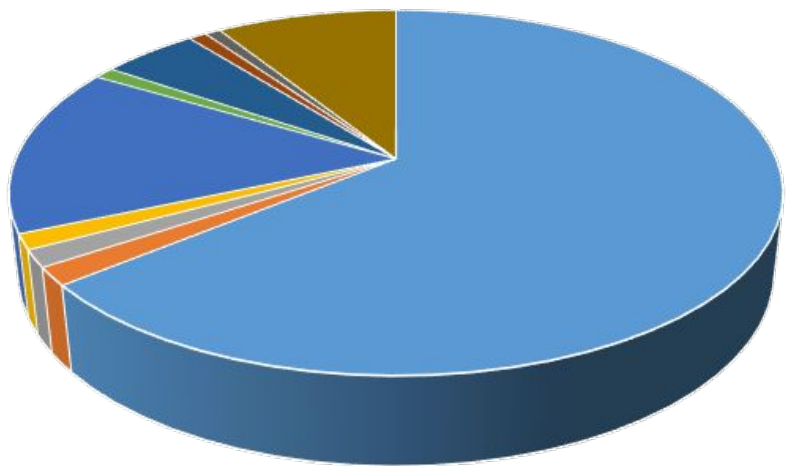

- Rice

- Flour

- Coarse cereal

- Vegetables

- Meat

- Eggs

(c)

$$
\begin{gathered}
\text { Japan } \\
\text { TDI }(i-A s)=23.8 \mu \mathrm{g} / \text { person } / \mathrm{d}
\end{gathered}
$$

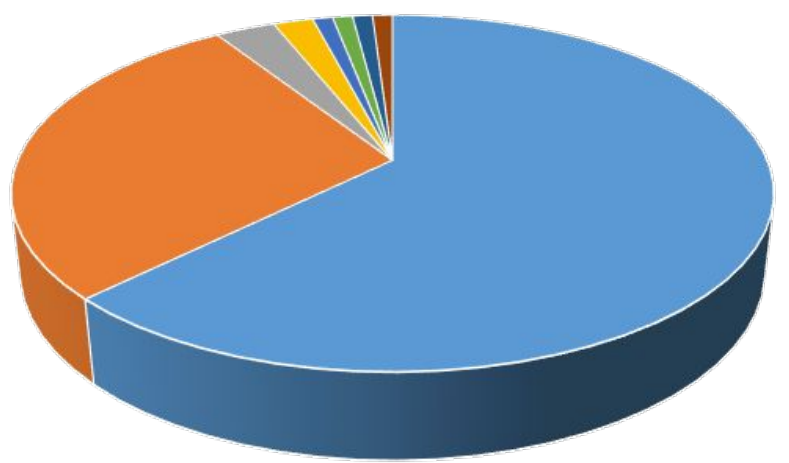

- Cereals

- Potatoes

- Algae

- Fishes and shellfishes - Beverages

- Supplemental nutrient - Others (b)

North China

TDI $(i-A s)=30.6 \mu \mathrm{g} /$ person $/ \mathrm{d}$

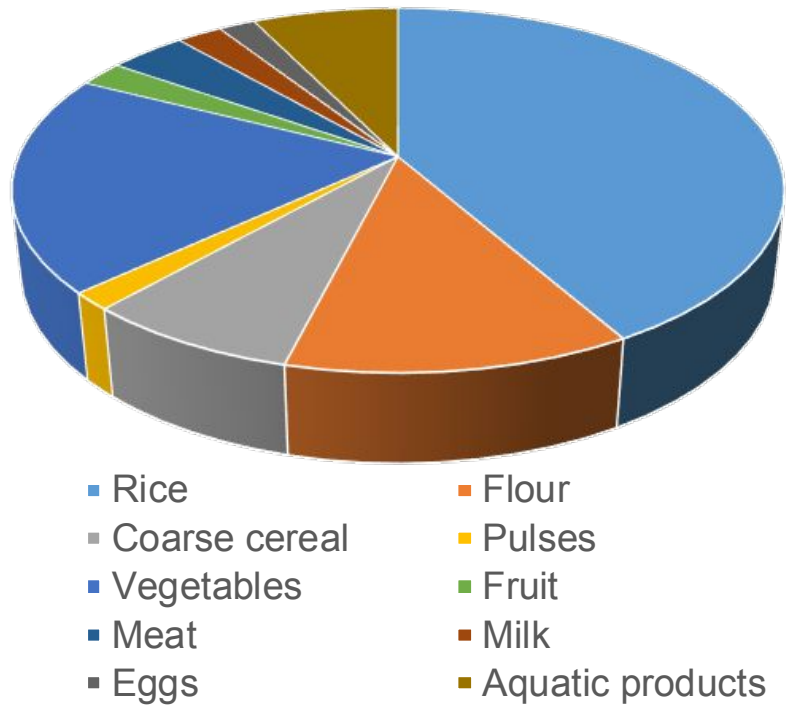

(d)

Vadodara, India

TDI $($ total As) $=9.1 \mu \mathrm{g} /$ person $/ \mathrm{d}$

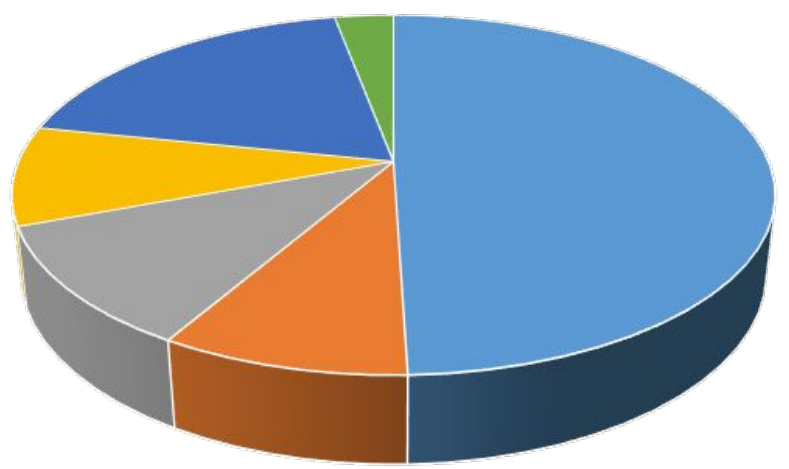

- Cereals

- Pulses

- Other vegetables

- Roots and tubers

- Green leafy vegetables - Fruits

- Milk

- Curd

Figure S2. Contribution of various foods to the total daily intake (TDI) of As in: (a) South China;

(b) North China; (c) Japan; and (d) Vadodara of India. With the exception of Vadodara, India, all the TDI estimates are for the population's intake of inorganic arsenic (i-As). Data for China from Li et al., ${ }^{9}$ data for Japan from Oguri et al., ${ }^{10}$ and data for Vadodara, India from Chandorkar et al. ${ }^{11}$ 


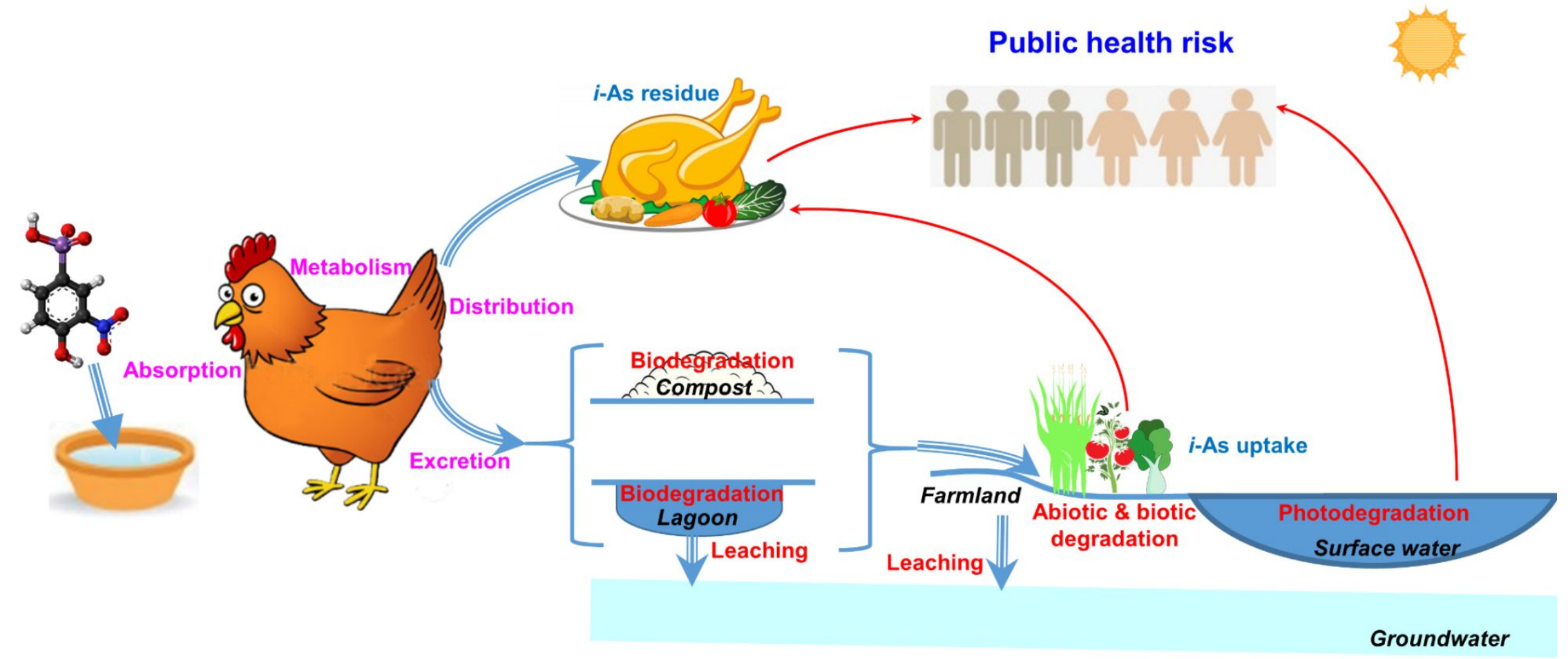

Environmental pollution

Figure S3. Schematic illustration on the fate of phenylarsonic feed additives used in animal farming and the corresponding risk to humans and ecosystem. 


\section{References}

1. U.S. Environmental Protection Agency (USEPA), Arsenic, inorganic (CASRN 7440-38-2).

Available at http://www.epa.gov/iris/subst/0278.htm (accessed June 10, 2019).

2. U.S. Environmental Protection Agency (USEPA), Risk Assessment Guidance for Superfund, Volume 1, Human Health Evaluation Manual (Part B, Development of Risk-Based Preliminary Remediation Goals), Report EPA/540/R-92/003. Washington, DC, 1991.

3. Hu, Y.; Zhang, W.; Chen, G.; Cheng, H.; Tao, S., Public health risk of trace metals in fresh chicken meat products on the food markets of a major production region in southern China. Environ. Pollut. 2018, 234, 667-676.

4. Hu, Y.; Zhang, W.; Cheng, H.; Tao, S., Public health risk of arsenic species in chicken tissues from live poultry markets of Guangdong province, China. Environ. Sci. Technol. 2017, 51, (6), $3508-3517$.

5. Nachman, K. E.; Baron, P. A.; Raber, G.; Francesconi, K. A.; Navas-Acien, A.; Love, D. C., Roxarsone, inorganic arsenic, and other arsenic species in chicken: a U.S.-based market basket sample. Environ. Health Perspect. 2013, 121, (7), 818-824.

6. Nachman, K. E.; Love, D. C.; Baron, P. A.; Nigra, A. E.; Murko, M.; Raber, G.; Francesconi, K. A.; Navas-Acien, A., Nitarsone, inorganic arsenic, and other arsenic species in turkey meat: Exposure and risk assessment based on a 2014 U.S. market basket sample. Environ. Health Perspect. 2017, 125, (3), 363-369.

7. Nigra, A. E.; Sanchez, T. R.; Nachman, K. E.; Harvey, D. E.; Chillrud, S. N.; Graziano, J. H.; Navas-Acien, A., The effect of the Environmental Protection Agency maximum contaminant level on arsenic exposure in the USA from 2003 to 2014: an analysis of the National Health and Nutrition Examination Survey (NHANES). Lancet Public Health 2017, 2, (11), e513-e521. 
8. National Bureau of Statistics, China Statistical Yearbook: 2018. China Statistics Press: Beijing, China, 2019.

9. Li, G.; Sun, G.-X.; Williams, P. N.; Nunes, L.; Zhu, Y.-G., Inorganic arsenic in Chinese food and its cancer risk. Environ. Int. 2011, 37, (7), 1219-1225.

10. Oguri, T.; Yoshinaga, J.; Tao, H.; Nakazato, T., Inorganic Arsenic in the Japanese Diet: Daily Intake and Source. Arch. Environ. Contam. Toxicol. 2014, 66, (1), 100-112.

11. Chandorkar, S.; Deota, P., Heavy metal content of foods and health risk assessment in the study population of Vadodara. Curr. World Environ. 2013, 8, (2), 291-297. 